\title{
Trends and Paths From Border Regions: The Frontier Centro-Castilla y León of Portugal and Spain*
}

\author{
Maria Manuela Santos Natário, Gonçalo José Poeta Fernandes \\ Polytechnic of Guarda, Guarda, Portugal \\ José Manuel Del Barrio Aliste, $\mathrm{M}^{\mathrm{a}}$ Luísa Ibáñez Martinez \\ University of Salamanca, Salamanca, Espanha
}

\begin{abstract}
The objective of this paper is to determine whether the process of European Union (EU) integration has unleashed a new territorial dynamic with the convergence of border regions. Authors intend to analyze trends and trajectories of the Portuguese-Spanish border regions of the Center of Portugal and Castilla y León, particularly the municipalities of NUTS III and northern and southern Beira Interior (Central Region) and the provinces of the municipalities of Salamanca and Zamora (Region of Castilla y León), in the last 20 years, given a set of demographic, economic, and social indicators, by using statistical analysis combined with contributions from the development processes established in these regions.
\end{abstract}

Keywords: economic development, border regions, trajectories

\section{Introduction}

The concern with the development of the Spanish-Portuguese border arose with two more acuity Iberian countries which entered the European Community. This has led to a situation in which regional disparities are aggravated by functional reconfigurations and perceptions of the weaknesses that these areas have, as they are now the widest border area of the community and also the most underdeveloped one. This disadvantaged and depressed territory constitutes a peripheral area away from the major centers of economic activity and political decision. Historically, they have been penalized in the political and socio-economic areas, which are impacting their economic and social organization.

With the economic, social, and technological change, plus the integration of the European Union (EU) and resulting interdependence of economies, the traditional role of the border has changed. This change can be seen in the reduction of inefficiencies and the recent development of harmonized management of cross-border areas. The creation of the single market and integration into EU led to the abolition of borders of the member states that had worked as an obstacle to the free movement of people, goods and services, and capital within the EU. The single market, therefore, promoted the development of relations with neighboring countries, strengthened

\footnotetext{
* Acknowledgements: UDI/IPG-Research Unit for Development of Inland. Maria Manuela Santos Natário, Ph.D., Polytechnic of Guarda, Guarda, Portugal. Gonçalo José Poeta Fernandes, Ph.D., Polytechnic of Guarda, Guarda, Portugal. José Manuel Del Barrio Aliste, Ph.D., University of Salamanca, Salamanca, Spain. M $^{\mathrm{a}}$ Luísa Ibáñez Martinez, Ph.D., University of Salamanca, Salamanca, Spain.

Correspondence concerning this article should be addressed to Maria Manuela Santos Natário, Polytechnic of Guarda, Av. Dr. Francisco Sá Carneiro, No. 50, 6300-559 Guarda, Portugal. E-mail: m.natario@ipg.pt.
} 
the position of the regions, and consequently promoted competition (Natário, 2005).

In this context, it is important to know whether the process of EU integration triggered a new territorial dynamism with a convergence of border regions and, at the same time, it analyzed trends and trajectories in the regions of the border Center of Portugal and Castilla y Leon - in particular of the municipalities of NUTS III Beira Interior Norte, Beira Interior South (the Central Region), and the districts of the Provinces of Salamanca and Zamora (the Region of Castilla y Leon).

This paper is divided into four sections. The first articulates and explores the literature on the dynamics of these territories. The second describes the methodology used and its logical processing of information, followed by the treatment and analysis of data in the third section. Finally, the results and conclusions are presented and discussed.

\section{Border Regions: Contextualization}

The border region of Portugal and Spain is described as deprived and depressed - a peripheral territory away from the major centers of economic activity and political decision. This has promoted the social deregulation and economic spaces, where development strategies have not been effective.

In fact, the border regions have a double periphery: both in terms of its geographical position and in relation to the centers of decision (Lange, 2011a), thus presenting asocial disadvantage, as well as economical and structural disadvantages. For decades, these regions were marginalized in relation to decision-making centers and limited by a real and legal barrier-the border. Their condition was such that in the 1960s, the Raia Iberian became known as the "frontier of underdevelopment" (Cabero Diéguez \& Caramelo, 2011; Lange, 2011a, 2012).

Given its reduced dynamic, evidenced by demographic indicators and a socio-economic status below the national average, these regions have been one of the main concerns related to the development and cohesion of the EU.

There is a significant structural backwardness of border regions Luso-Spanish that led to the creation of the Operational Program for the Development of Border Regions (INTERREG) Portugal/Spain. The program's objective is to move the communities in the direction of greater integration and economic and social convergence in the European Community. It was only after the creation of the INTERREG initiative that the European Community has clearly recognized the need to develop the border areas and stimulate cross-border cooperation among neighboring populations that have been separated for centuries (Lourenço, 1996).

After the success of the first generation of the INTERREG program (1990-1993), it has been renewed multiple times from 1994 to 1999 and from 2000 to 2006, and more recently from 2007 to 2013 as the cross-border Cooperation Operational Program Spain-Portugal (POCTEP) (Lange, 2012).

The effort and joint cooperation between Portugal and Spain begins with the establishment of democratic regimes in the 1970s and, especially, with the joint accession to the EEC in 1986, which marks the end of a long relationship tense and combative. (Lange, 2011a, p. 1575)

The creation of the single market and integration in EU led to the abolition of the member states' borders that had worked as an obstacle to the free movement of people, goods and services, and capital within the EU. The single market, therefore, promoted the development of relations with the neighboring countries, and strengthened the region's position, and consequently, promoted competition (Natário, 2005). 
Although abolished, borders, legal borders, and others, have arisen, according to Reigado and Almeida (1994), Lourenço (1996), and Reigado (2002), the borders, psychological boundaries, and counter powers have slowed down the development of cooperation between Portugal and Spain. There are economic borders and social borders, as well as institutional boundaries; there are also cultural boundaries, limitations of language, and budgetary constraints that create obstacles as well.

But the abolition of borders does not guarantee positive effects on the development of border regions. As Reigado (1993) has stated, in the border regions, the development of relations with the neighboring countries will have, at the same time, an increase in pressures (for example, in the field of migration flows) and new business opportunities.

Over the past few years, there has been favorable territorial dynamics- "reducing border" (Salgado, 2010) characterized by new structures and by many initiatives that have sought to stimulate cooperation among the border regions. Lange (2011b) identified several types of cross-border cooperation and objectives in different territorial levels, with a more "macro" character. In particular, the creation of macro-regions and the Euro-regions is considered as platforms where several structures that promote cooperative development. The communities themselves serve as the major promoters of cooperation along their borders. In this context, they are creating more central initiatives, such as the European Territorial Cooperation, twinning arrangements, and the introduction of the European Grouping of Territorial Cooperation (EGTC). It is true that the proliferation of these initiatives was only possible because of community funds.

In fact, the objective of cross-border cooperation is to create opportunities for the development of these marginal areas. It is for this reason that cross-border cooperation is an important factor in development, because, according to Reigado (2002), development will take place at the cross-border level: the economies of scale, planning of public services, organization of transportation systems and communications, urban development, and the joint promotion of economic activities along with scientific and technological development.

The EU has increasingly begun to recognize the importance of this form of cooperation in achieving one of the three primary goals of European Territorial Cooperation. Therefore, there has been an effort to institutionalize cross-border relations in Europe. This effort seeks to establish more effective structures and formal agreements to facilitate and deepen the cooperation by establishing contacts and informal pacts (Lange, 2011a).

However, cross-border cooperation has not yet achieved its main goals as there still exist difficulties due to the limitations caused by the important role played by the states (countries). There are still major differences and asymmetries, as well as a historical inertia that causes both sides of the border to remain resistant and fearful (Salgado, 2010).

In this context, once the legal boundaries between Portugal and Spain have been abolished, the countries which seek to enhance relations and cooperation among border regions (cross-border), will have triggered a new dynamic with convergence of border regions. Or on the contrary, will there be a trend in favor of concentration for the more advanced regions, leading to a reordering of economic territory to the detriment of the poorest regions, as Reigado (2002) already questioned? These are questions that demand answers, which is what the next sections of this work attempt to do.

\section{Methodology and Results}

In this study, authors intend to analyze the trends and trajectories of the border regions Centro-Castilla y 
Leon de Portugal, in particular, the 13 districts in the NUTS III Beira Interior Norte (BIN), Beira Interior South (BIS) (the Center Region), and the five districts of the Provinces of Salamanca and Zamora (the Region of Castilla y Leon). The districts are Almeida, Celorico da Beira, Figueira de Castelo Rodrigo, Guarda, Manteigas, Meda, Pinhel, Sabugal, and Trancoso from BIN; Castelo Branco, Idanha-a-Nova, Penamacor, and Vila Velha de Ródão from BIS; Ciudad Rodrigo and Vitigudino of the province of Salamanca and Aliste and Sanabria e Sayago from the province of Zamora.

The main source of data used was the INE of Portugal and Spain for the years 1991, 2001, and 2011. The study focuses on a total of 18 municipalities and/or judicial districts.

The methodology used for the analysis is based on the application of multivariate statistical, cluster analysis, in order to group the regions, according to their demographic trend. In particular, the regions are grouped in terms of growth rates from 1991 to 2011: the population (Population growth rate 91_11), the population density (Density growth rate 91_11), natural growth (Natural growth rate 91_11), migration balance (Migratory growth rate 91_11), foreign population (Foreign Population growth rate 91_11), and unemployment (Unemployment growth rate_2001_11). These were subsequently applied multiple means comparison tests to distinguish the unique characteristics of each cluster and assess the main dimensions of these trends.

The use of the methodology of the analysis of clusters proved to be adequate and the variables for achievement of objectives used to classify regions were all significant for the solution found, as can be seen by the results of the ANOVA analysis, which are listed in Table 1.

Table 1

ANOVA Analysis

\begin{tabular}{lrrrrrr}
\hline & \multicolumn{2}{c}{ Cluster } & \multicolumn{2}{c}{ Error } & \multirow{2}{*}{ Sig. } \\
\cline { 2 - 6 } & Mean square & $d f$ & Mean square & $d f$ & & \\
\hline Growth rate_2011 & 748,645 & 2 & 44,429 & 15 & 16,850 & 0.000 \\
Population growth rate 91_11 & 849,856 & 2 & 52,197 & 15 & 16,282 & 0.000 \\
Natural growth rate 91_11 & $244,469,122$ & 2 & $1,836,839$ & 15 & 133,092 & 0.000 \\
Migratory growth rate 91_11 & $363,673,094$ & 2 & $15,493,442$ & 15 & 23,473 & 0.000 \\
Population growth rate by stratum_91_11 & $1,564,918,389$ & 2 & $53,463,691$ & 15 & 29,271 & 0.000 \\
Unemployment growth rate_2001_11 & $6,677,044$ & 2 & $1,770,324$ & 15 & 3,772 & 0.047 \\
\hline
\end{tabular}

By applying the methodology described above for cluster analysis, three groups were used (Table 2 and 3 ). The first, consisting of three municipalities, it is characterized by a decrease in the population by $12 \%$, the population density by $12 \%$, and a net migration 1 of $52 \%$, but with a positive natural growth (difference between the number of births and the number of deaths) of $25 \%$, which resulted in a strong increase of the foreign-nationality resident population along with the greatest growth in terms of unemployment. The second cluster with only one county, presents positive values in all dimensions in the analysis. The third group, consisting of 14 municipalities, presents the greatest population decline, which only compensated for by an increase of the foreign population in these counties/districts, as can be seen in Table 2.

Given its characteristics, group 1, consisting of Pinhel, Trancoso, and Castelo Branco, shows no convergence in terms of population and economy, which denotes an average divergence in terms of demographic sustainability and a high divergence in economic terms from the increase in unemployment. The

\footnotetext{
${ }^{1}$ Net migration (the difference between the number of immigrants and the number of emigrants).
} 
second cluster with one county, Guarda, remained steady in demographic terms and presented some convergence with the national average albeit at the expense of the draining of neighboring municipalities and the increase in the foreign population, but it was also marked by worsening economic conditions evidence by a steep increase in unemployment. The third cluster is the one that presents the greatest divergence and is composed of the remaining municipalities in the analysis (Table 3), noting the drain of population. Clearly, the process of EU integration has not triggered the convergence of regions. On the contrary, it has created a gap and divergence.

Table 2

Cluster Analysis

\begin{tabular}{|c|c|c|c|}
\hline \multicolumn{4}{|l|}{ Final Cluster Centers } \\
\hline & Cluster 1 & Cluster 2 & Cluster 3 \\
\hline & $N=3$ & $N=1$ & $N=14$ \\
\hline Growth rate_2011 & -11.63 & 10.50 & -25.16 \\
\hline Growth rate_91_11 & -12.03 & 11.10 & -26.68 \\
\hline Natural growth rate 91_11 & 25.27 & 741.70 & 21.56 \\
\hline Migratory growth rate 91_11 & -52.10 & 850.00 & -20.51 \\
\hline Population growth rate by stratum _91_11 & $1,580.10$ & $2,154.00$ & 760.96 \\
\hline Unemployment growth rate_2001_11 & 135.00 & 112.00 & 64.71 \\
\hline
\end{tabular}

Table 3

Municipalities Per Cluster

\begin{tabular}{|l|l|l|}
\hline Cluster 1 & Cluster 2 & Cluster 3 \\
\hline Pinhel & Guarda & Almeida \\
\hline Trancoso & & Celorico da Beira \\
\hline Castelo Branco & & Figueira de Castelo Rodrigo \\
\hline & & Manteigas \\
\hline & & Meda \\
\hline & & Sabugal \\
\hline & & Idanha-a-Nova \\
\hline & & Penamacor \\
\hline & & Vila Velha de Ródão \\
\hline & & Ciudad Rodrigo \\
\hline & & Vitigudino \\
\hline & & Aliste \\
\hline & & Sanabria \\
\hline
\end{tabular}

According to Reigado (2002), in addition to the positive consequences, there has also been a reduction in costs and the economic growth that could lead to the opening of borders. Emerging concentration trends for the development of more advanced regions have leaded to a reordering of economic European territory to the detriment of poorer countries and regions, exacerbating inequalities existing in U. E.

This result is further confirmed by the results presented in Figure 1. In fact, the highest population density (60 inhabitants per $\mathrm{km}^{2}$, against 115 inhabitants per $\mathrm{km}^{2}$ in Portugal and 93 inhabitants in Spain) in 2011 is found in the municipality of Guarda and the majority of the municipalities of the border region of Center/Castilla y Leon (a concentration of less than 30 inhabitants per $\mathrm{km}^{2}$ ). Moreover, except for the municipalities of Guarda and Castelo Branco, all remaining municipalities in the analysis showed a decrease in population density over the last 20 years (1991 to 2011) (Figure 2). 


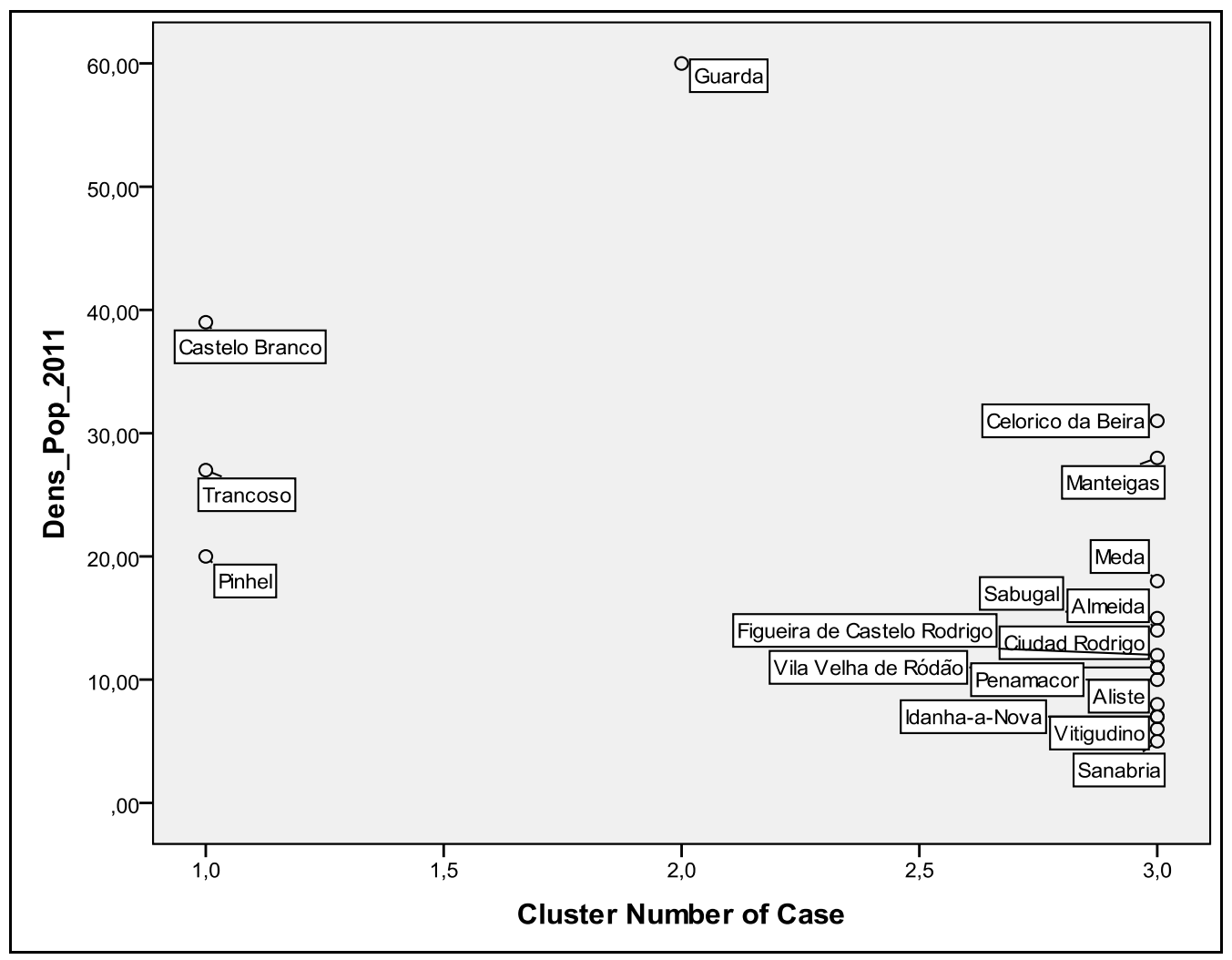

Figure 1. Population density per cluster in 2011

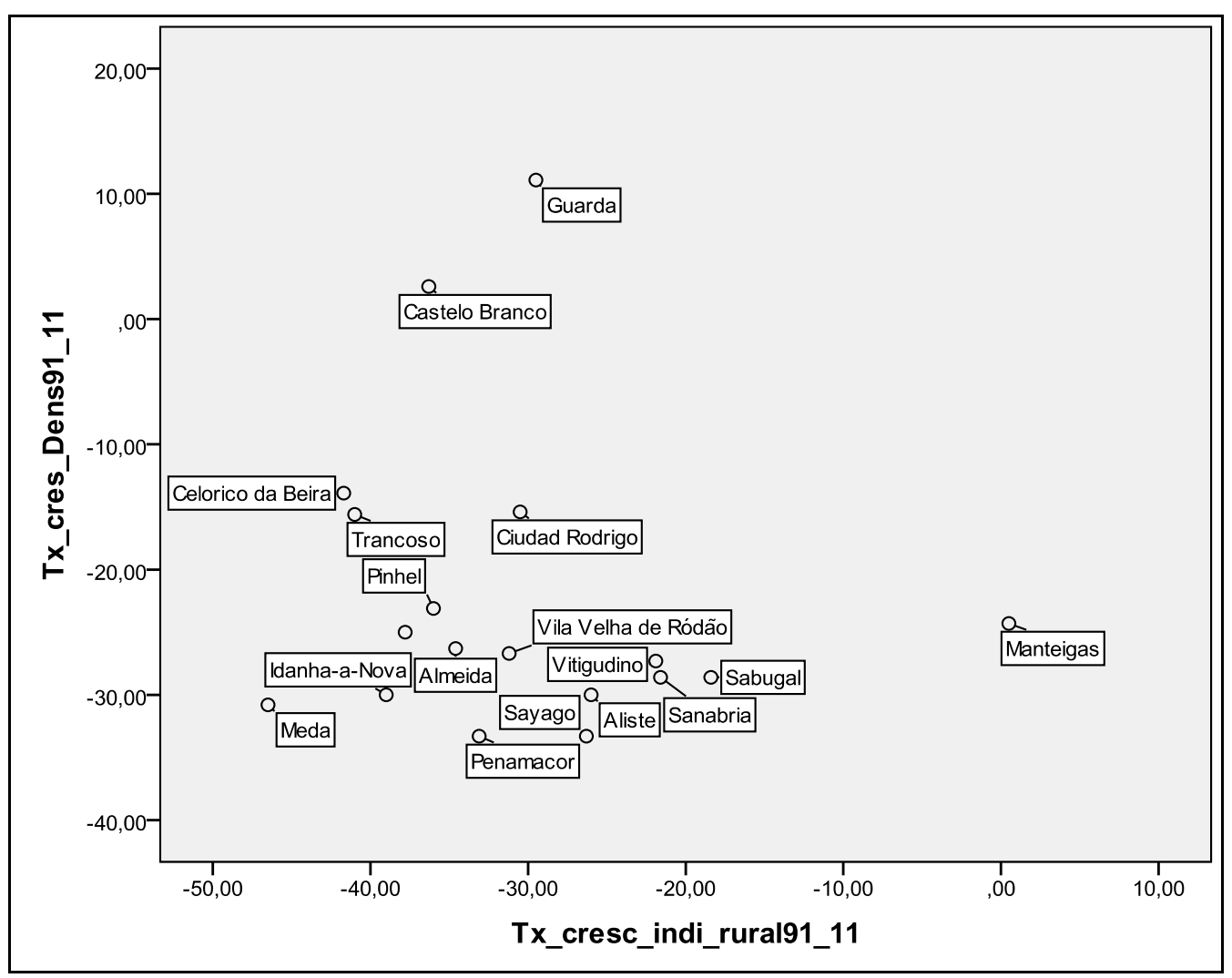

Figure 2. Trajectories in terms of index of rurality versus population density. 
In order to determine which factors distinguish the three groups of municipalities, authors have used Anova and applied the test as a mean to analyse the differences among the groups. Table 4 contains the results of the Anova analysis, which shows that the three groups vary in terms in the Aging Index 2011, resident population of foreign nationality in 2011, population in terms of age structure in 2011, and the number of agricultural holdings in 2009. The size of farm (number of farms according to age group), the effective of animals in 2009, the young persons $(<25$ years) registered as unemployed in job centers (number), and the index of rurality (number of people who live in places with less than 2,000 inhabitants) did not show a statistically significant difference among the clusters.

In relation to the index of aging and the population of more than 65 years old, the tests of mean differences conclude that the third cluster shows higher average values, followed by the first cluster. The second cluster boasted the best results in terms of resident population of foreign nationality, and in terms of population age structure in 2011. Group 1 has the greatest number of farms.

Therefore, the aging of the population and the reduction of the population of either the young or those in active age, which has been offset by a foreign population, influence the group of municipalities, creating a greater divergence with worsening of the periphery and inequalities, as well as increasing the distance from the other regions of the EU.

Table 4

ANOVA Analysis and Test of Mean Differences

\begin{tabular}{lllll}
\hline & $d f$ & $F$ & Sig. & Mean differences \\
\hline Ageing index_2011 & 2 & 4.101 & 0.038 & $3>1>2$ \\
Pop_est_2011 & 2 & 8.254 & 0.004 & $2>1>3$ \\
Pop0_14_2011 & 2 & 6.545 & 0.009 & $2>1>3$ \\
Pop15_24_2011 & 2 & 4.102 & 0.038 & $2>1>3$ \\
Pop25_64_2011 & 2 & 5.170 & 0.020 & $2>1>3$ \\
Pop_m65_2011 & 2 & 7.354 & 0.006 & $3>1>2$ \\
Exp1_0_5ha_2009 & 2 & 1.038 & 0.378 & \\
Exp1_5_20ha_2009 & 2 & 0.496 & 0.619 & \\
Exp1_20_50ha_2009 & 2 & 1.699 & 0.216 & \\
Exp1_m50ha_2009 & 2 & 1.361 & 0.286 & \\
Number of farms_2009 & 2 & 4.971 & 0.022 & $1>2>3$ \\
Ef_animals_2009 & 2 & .557 & 0.584 & \\
Unemployed young people_2011 & 2 & 2.636 & 0.104 & \\
Rural rate_2011 & 2 & 1.208 & 0.326 & \\
\hline
\end{tabular}

An analysis of the various dimensions of municipality trajectories shows that Castelo Branco and Guarda, apart from other municipalities, present the best results in terms of population and population growth, converging to values above 40,000 inhabitants. The vast majority of the frontier municipalities in the analysis have less than 20,000 inhabitants, having seen a decrease in population over the past 20 years (Figure 3).

The third graph continues to show the co-existence in frontier territory of three different situations and territorial dynamics in terms of natural growth and population density from 1991 to 2011 . The graph shows the territories with positive gains in these two indicators (Guarda and Castelo Branco), other Municipalities groups with rates of natural growth from 1991 to 2011, but with a decrease in population density (Celorico da Beira, Meda, Pinhel, Sabugal, Trancoso, Idanha-a-Nova, Penamacor, Aliste, and Sayago) and a third dynamic that is 
negative in the two indicators (Figueira Castelo Rodrigo, Manteigas, Vila Velha de Ródão, Ciudad Rodrigo, Vitigudino, and Sanabria).

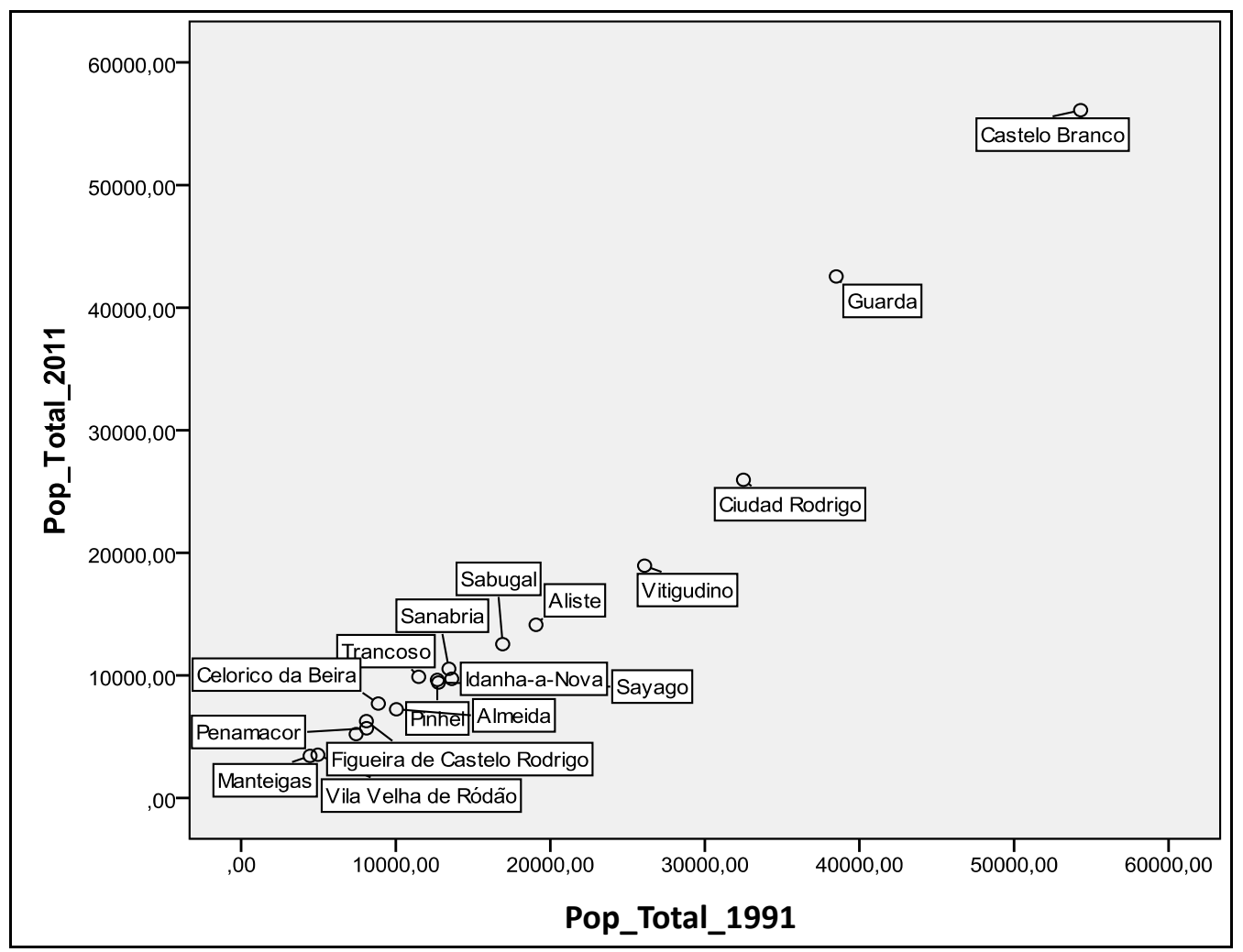

Figure 3. Trajectories of the frontier regions population.

These results are, in part, justified by the changes in the birth rate and mortality rate in these regions (Figure 4). In fact, except in Vitigudino, all municipalities in the analysis have had their birthrate increase from zero or negative, which was accompanied by increases in the rate of mortality, which was a result of an aging population.

From the results lists in Figure 5, it can be seen that in the period from 1991 to 2011, the rate of growth of net migration (the difference between the number of immigrants and the number of emigrants) increased in the municipalities of Sanabria, Aliste, Sayago, Trancoso, Vila Velha de Ródão, and Ciudad Rodrigo, while unemployment decreased in most municipalities except for those of Vila Velha de Ródão, Idanha-a-Nova, and Penamacor.

The index of rurality (the number of people who live in nuclei of less than 2,000 inhabitants per total population of the territory in analysis) shows that during the period under review, all municipalities saw a decrease in their index of rurality except for Manteigas (Figure 6).

According to the data from the Figure 7, which continues to focus on the period from 1991 to 2011, three different situations, along with different territories' dynamics in terms of rurality and collection of waste, co-existed in frontier territory. The territories have seen gains in terms of waste collection (number of buildings with selective collection of waste), but losses in terms of rurality index (the vast majority of municipalities in analysis). In other territories, there has been a combination of losses both in terms of collection of waste and terms of rurality index (Meda and Idanha-a-Nova). Finally, others have increases both the rurality index and waste collection, although with very low values (Manteigas). 


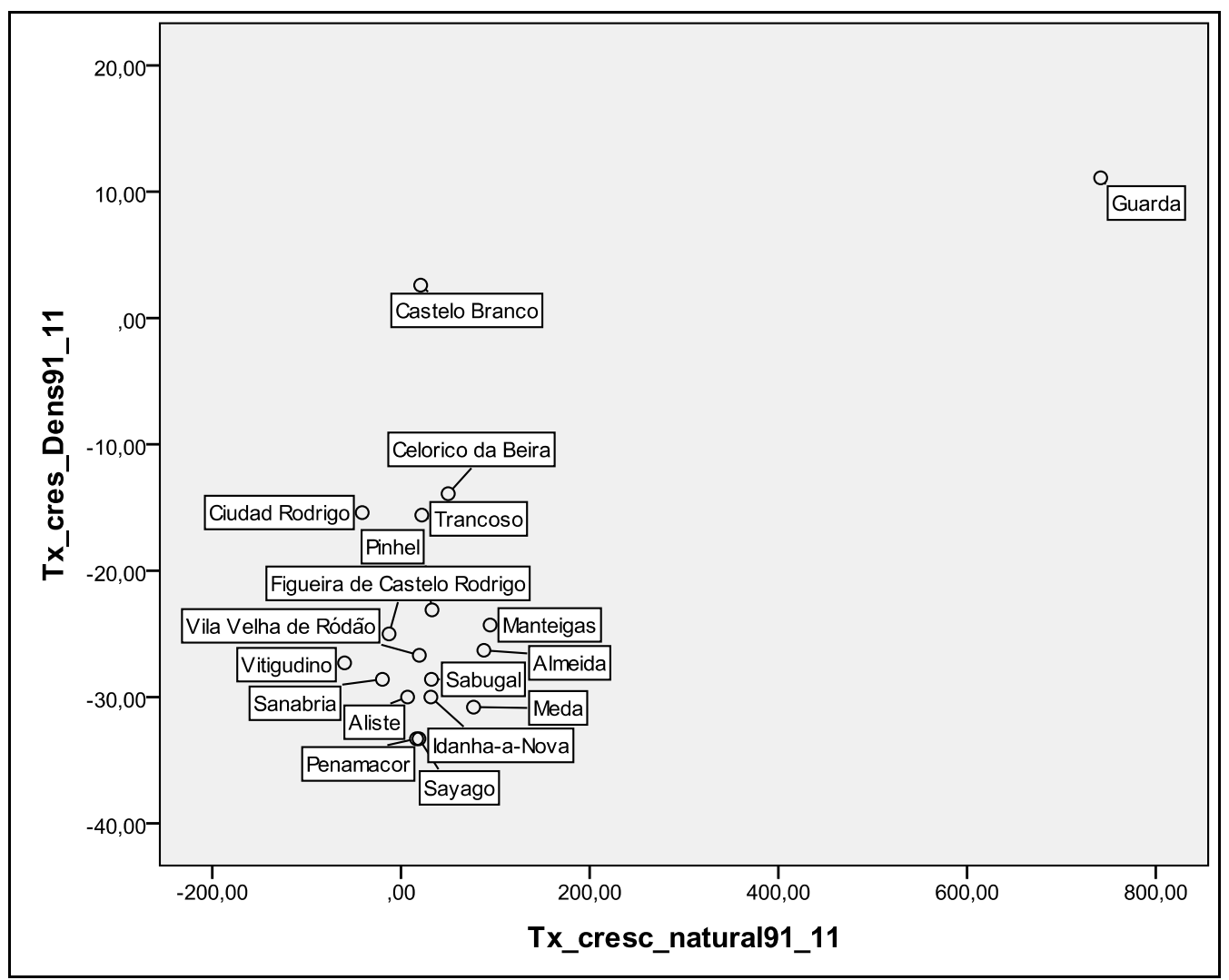

Figure 4. Trajectories in terms of natural growth and population density of border regions.

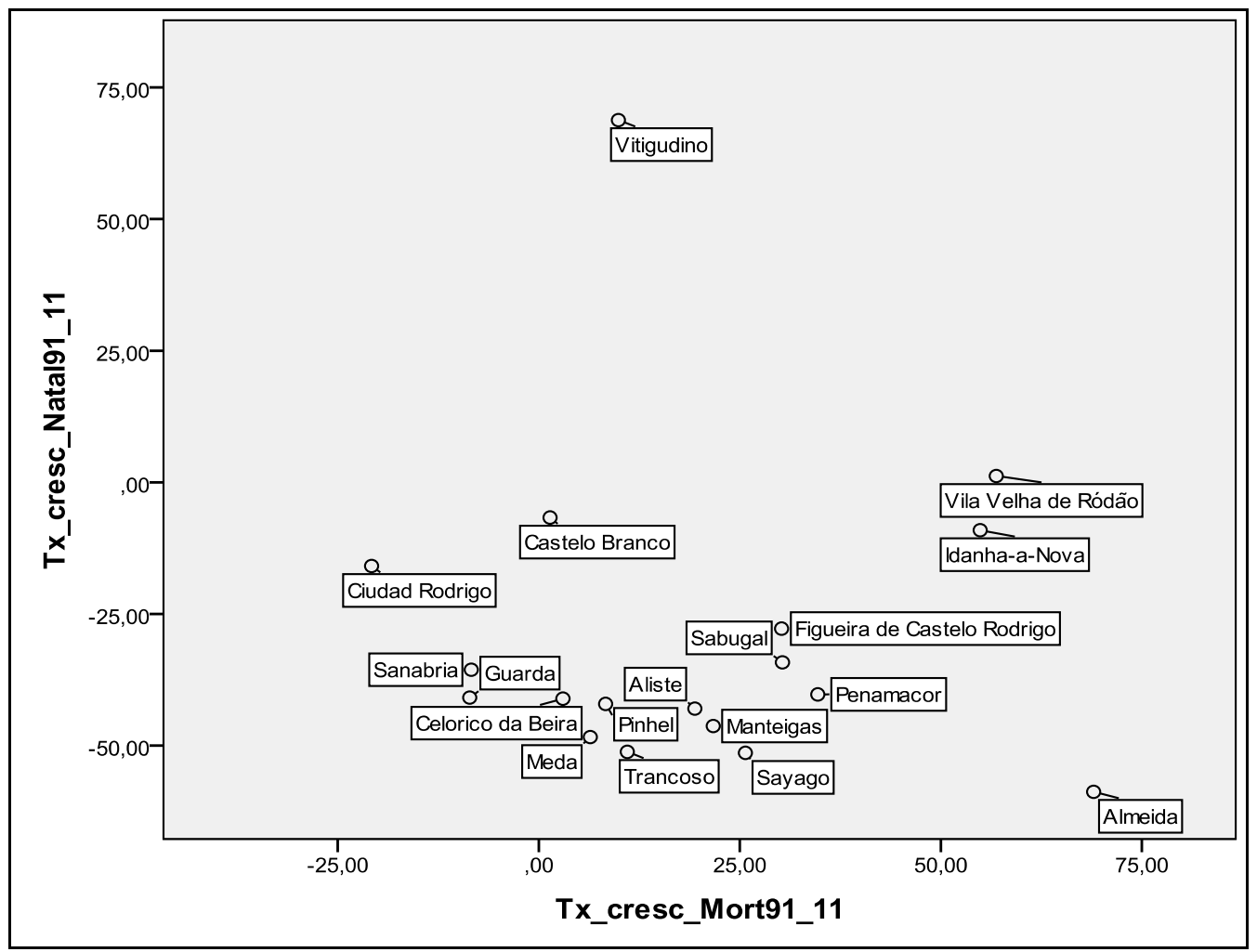

Figure 5. Trajectories in terms of growth in the birth rate and mortality. 


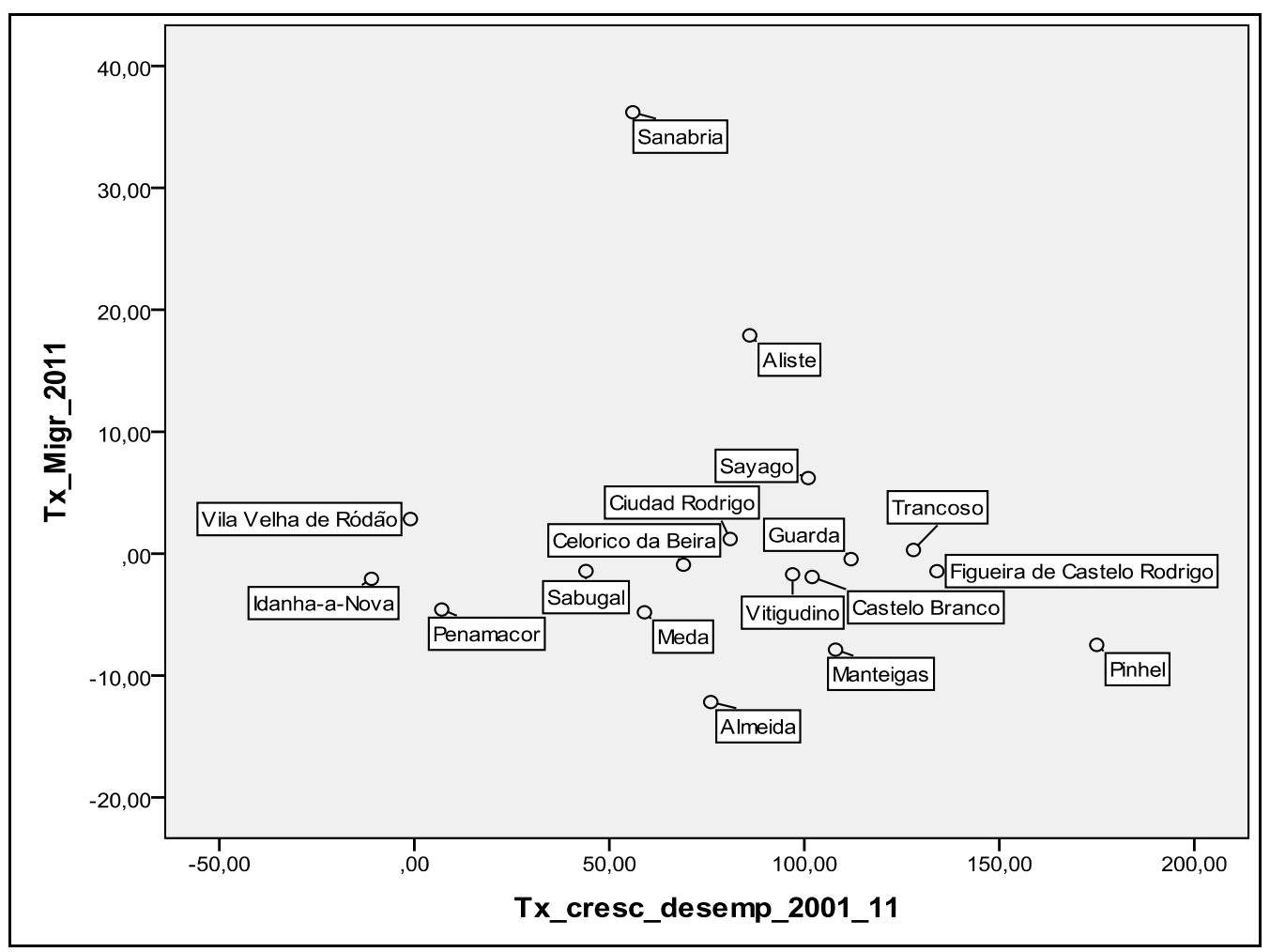

Figure 6. Trajectories in terms of net migration and unemployment of border regions.

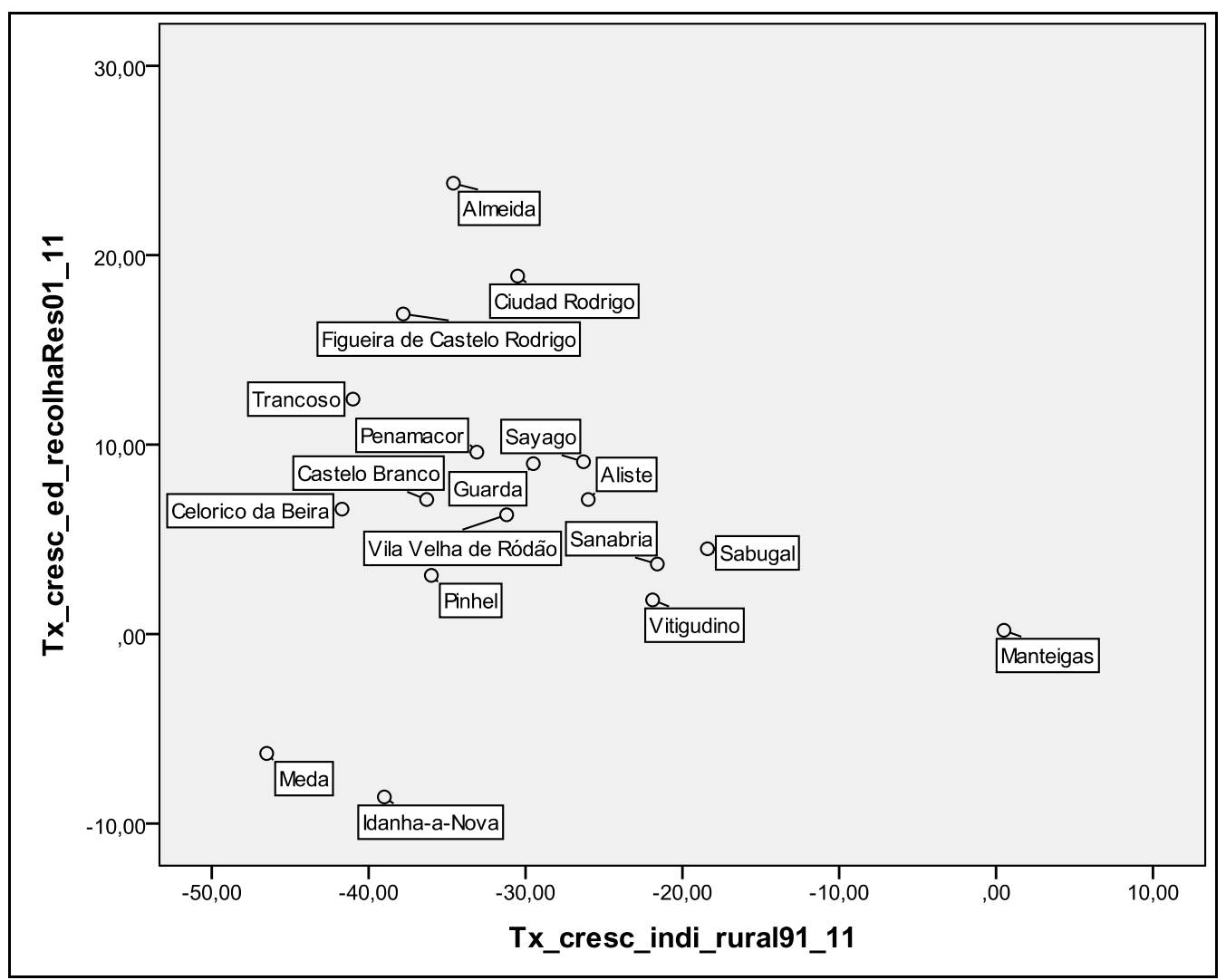

Figure 7. Trajectories in terms of index of rurality versus waste collection. 
Accompanying the phenomenon of a reduction in rurality, was a reduction in the number of farms in all municipalities. It should be noted that the greatest reduction in the number of agricultural holdings was seen in Sanabria (Figure 8). From this, authors can then highlight two different territorial dynamics (Figure 8) and analyze the agricultural holdings and the number of animals. A general dynamic is seen across territories with gains in terms of animals effective, even though there has been a decrease, sometimes a sharp decrease, in the number of farms (all municipalities bordering the Spanish part and Idanha-a-Nova). On the other side are the territories that combine losses in terms of agricultural holdings and animals effectives (the other municipalities of the BIS and all the municipalities of BIN).

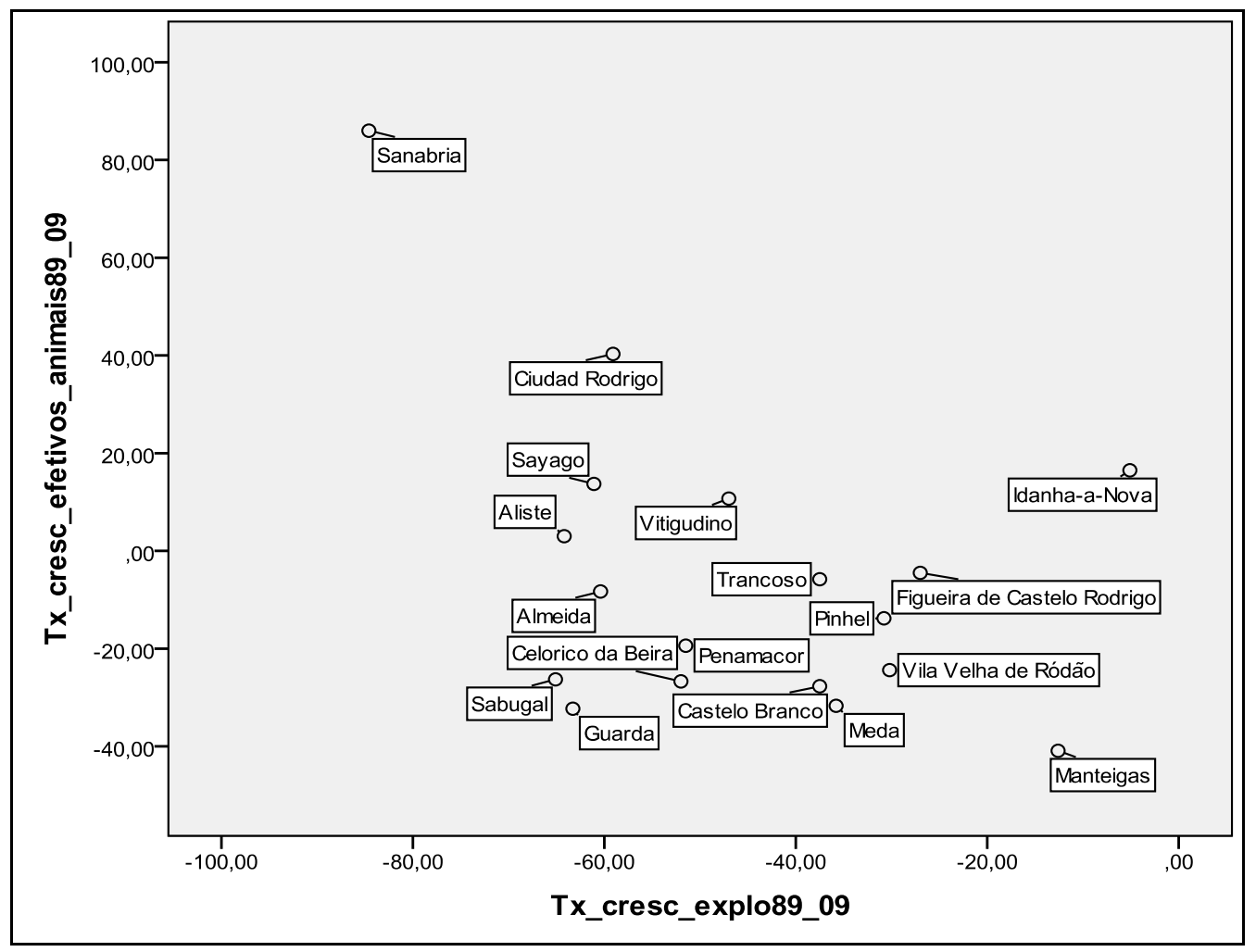

Figure 8. Trajectories in terms of agricultural holdings versus effective animals.

\section{Conclusions}

The structural development problems that border regions face include the territorial specificity of these spaces. These constraints have lost their force with the expulsion of the raia/raya, particularly in the districts where the urban characteristics exacerbate the existence of industrial activities and services, which provide better welfare conditions for their communities. In practice, the frontier municipalities behave in a heterogeneous manner in this study. The combination of demographic and functional indicators does not show clear territorial patterns, despite the clear influence from their geographical proximity to the border. The consideration of municipalities, within the framework of NUT III identified border, with geographic, economic, and demographic profiles of the municipalities, within the framework of NUT III identified border, was very different, which makes determining typification or evolution patterns difficult.

The cross-border cooperation and community programs have failed to meet the main objectives proposed as they did not to create a new dynamic as border regions failed to converge. On the contrary, due to the large 
differences and asymmetries in relation to other regions of the country, concentration trends for the more advanced regions and the coast appeared, which lead to a reordering of economic territory to the detriment of the poorest regions of the border. This eventually led to almost draining of population and services to these regions. Policies and community-incentive measures have not stopped these downward trends, putting into question their own sustainability in the very short term.

\section{References}

Cabero Diéguez, V., \& Caramelo, S. (2001). The evolution of the Spanish-Portuguese border and the process of European integration. Proceedings from 41st Congress of the European Regional Science Association, 29 Agosto-01 Setembro, Zagreb.

Lange, E. (2011a). A Cooperação Transfronteiriça Institucional na Região Norte de Portugal—Sobreposição ou Complementaridade (Institutional cross-border cooperation in the north of Portugal-Overlay or complementarity)? Proceedings from 17th APDR Congress-Management of commons goods and sustainable regional development, Junho/Julho 2011, Bragança.

Lange, E. (2011b). EGTC-A "breath of fresh air" for practical cross-border cooperation. Tracing the legal cross-border co-operation from the European level to the Galicia-North of Portugal cross-border region. Proceedings from Regional Studies Association Annual International Conference 2011, Newcastle.

Lange, E. (2012). De 'Países Subdesenvolvidos' à 'Fronteira do Subdesenvolvimento-Contributo para um Debate Conceitual do Desenvolvimento (Underdeveloped countries to frontier of underdevelopment - Contribution for a conceptual development). Proceedings from 18th APDR Congress-Innovation and regional dynamics, Junho 2012, Faro.

Lourenço, A. (1996). Análise da Competitividade/Cooperação entre o Concelho do Sabugal e a Comarca de Ciudad Rodrigo: Cooperação Transfronteiriça (Dissertação de Mestrado, Universidade da Beira Interior, Covilhã).

Natário, M. M. (2005). Innovation, competitiveness, and business demography: The case of Raia Central Ibérica (PhD Thesis, University of Évora, Março).

Reigado, F. M. (1993). Raia Central e Desenvolvimento Transfronteiriço (Seminário sobre Integração Europeia e Diferenciação: Contributos para o Desenvolvimento Local, Instituto para o Desenvolvimento Agrário da Região Centro, Coimbra, 7 de Abril).

Reigado, F. M. (2002). Desenvolvimento Regional Transfronteiriço. In J. S. Costa (Ed.), Compêndio de Economia Regional (pp.571-596). Coimbra: Colecção APDR.

Reigado, F. M., \& Almeida, C. (1994). Estratégias de Desenvolvimento Transfronteiriço (Papeles de Economia Española, Fundación Fondo para la Investigatión Economica y Social, Junta de Castilla y León, Federación de Cajas de Ahorros de Castilla y León, 14, Salamanca).

Salgado, A. R. (2010). La cooperación transfronteriza y sus consecuencias: hacia la reestructuración territorial en Europa. Investigaciones Regionales, 18, 141-152. 